\title{
RECOGNITION AND ENFORCEMENT OF Foreign Arbitral AWARdS IN CIVIL AND COMMERCIAL MATTERS IN ETHIOPIA
}

Tecle Hagos Bahta *

\begin{abstract}
Ethiopia is not yet party to the New York Convention on the Recognition and Enforcement of Foreign Arbitral Awards. It can also be said that Ethiopian arbitration laws fail to cope with the emerging modern laws and practices in international commercial arbitration. However, as of 1965, with the introduction of the Civil Procedure Code (CPC), rules on the recognition and enforcement of foreign judgments and arbitral awards are set out whose interpretation, unfortunately, have remained thus far inconsistent. Thus, the criteria must be clearly interpreted and applied so that the rules can be conducive to the steadily increasing practice of modern arbitration. This article attempts to shed some light on these conditions.
\end{abstract}

\section{Key words:}

Foreign arbitral awards, commercial arbitration, enforcement of foreign judgments, Ethiopia.

\section{Introduction}

Commercial arbitration is becoming increasingly indispensable in international trade. The ease of enforceability of arbitral awards across borders should have, inter alia, been the driving factor for the eminence of international commercial arbitration in international trade. Thus, award-creditors may need to move across borders looking for a forum within which the award-debtor might have placed or deposited sufficient assets towards the satisfaction of the arbitral award.

* LL.B (AAU, 2002), LL.M: European and Comparative Law (University of Ghent, 2006), $\mathrm{PhD}$ candidate (University of Warwick Law School), Assistant Professor of Law, Mekelle University, College of Law and Governance, Department of Law. The author can be reached at <pppillars@fastmail.fm> 
It is believed that once an arbitral award is rendered, the award-debtor unconditionally complies ${ }^{1}$ with it or attempts to negotiate for discounted settlement over the arbitral award, or, at times, refuses to comply with it at all. In the second scenario, the award-creditor may have to trade-off between the offer and the available options. The third scenario, however, leaves the awardcreditor with no option but to pursue legal action ${ }^{2}$ in the optimal forum for the 'recognition and enforcement of the foreign arbitral award'.

States favorably tend to recognize arbitral awards rendered in other countries with the objective of avoiding continued harassment against the defendant, waste of time, money and effort and with the view to promoting international investment and trade. In so doing, to ensure that proper justice is administered, it is expected that national courts should ascertain that any foreign arbitral award is free from substantial defects which may hinder its enforcement in the state in which recognition and enforcement is sought.

This article is aimed at expounding the conditions set out under Article 461 of the Civil Procedure Code for the recognition and enforcement of foreign arbitral awards. Incidentally, however, an attempt has also been made to put the doctrine of reciprocity in its proper perspective in its application not only to the recognition and enforcement of foreign arbitral awards but also to foreign judgments.

\section{Recognition and Enforcement/Execution: The Conceptual Framework}

\section{1- Execution or Enforcement}

'Execution' or 'enforcement ${ }^{\text {, }}$ of foreign judgments and arbitral awards should be distinguished from the actual attachment and sale of property in satisfaction of the judgment or award decree. This article does not deal with the procedures

${ }^{1}$ S. Azadon Tiewul and Francis A. Tsegah, (1975) 'Arbitration and The Settlement of Commercial Disputes: A Selective Survey of African Practice’, Int'l \& Comp. L. Q, vol. 24, at 410 (“... compliance with arbitral awards is in most cases voluntary because of the desire of the parties to continue their business relationship and the spirit of goodwill which is engendered by the resort to arbitration rather than the courts.")

2 Ibid, ("For people to have confidence in any system of arbitration, there must be a mechanism whereby the award rendered can be enforced").

${ }^{3}$ It seems that the draftsman of the CPC preferred to use the terms 'execution' and 'enforcement' interchangeably [Art.15(3)]; thus, the consistent usage of the term 'execution' for foreign judgments [Arts.456-460] and 'enforcement' for foreign arbitral awards [Art.461] could only be taken to serve the purpose of observing internal consistency rather than intending to treat them differently. 
of attachment or other procedures by which the decision in the award will be carried out. Such technical procedures, which are different in all countries of the world, are not the purpose of this Article; furthermore, they present nothing special as far as arbitration is concerned. The purpose of this Article is rather only to scrutinize the litmus paper under which an arbitral award classified as 'foreign' must pass so as to merit a 'go-ahead' order by the Ethiopian courts by which the claim embodied in it may earn the status of having full legal force and be enforced by the claimants.

\section{2- Recognition and Enforcement}

Briefly put, the difference between recognition and enforcement is that, "an award may be recognized, without being enforced; but if it is enforced, then it is necessarily recognized by the court which orders its enforcement." 4 Thus, an award-creditor in a foreign arbitral award may seek only for its recognition or its recognition and enforcement. ${ }^{5}$ The purpose of recognition on its own is to act as a shield; it is used to block any attempt to initiate fresh proceedings, issues which have already been decided in the arbitration that gave rise to the award whose recognition is sought. ${ }^{6}$ The purpose of enforcement is, however, to 'act as a sword, not a shield'.

The recognition of an award by a court gives a res judicata effect thereto. Enforcement, however, goes a step further than recognition. As Redfern and Hunter noted, “... where a court is asked to enforce an award, it is asked not merely to recognize the legal force and effect of the award, but also to ensure that it is carried out by using such legal sanctions as are available". 8 Thus, the terms 'recognition' and 'enforcement' can be used together where the latter is the necessary follow-up of the former in judgments and awards which carry pecuniary obligations.

The difference between 'recognition' and 'enforcement' is further summarized as follows: ${ }^{9}$

Recognition is an undertaking by a state to respect the bindingness of foreign arbitral awards. Such awards may be relied upon by way of defence or set-off in any legal proceedings concerning the subject- matter of the award commenced in

\footnotetext{
${ }^{4}$ Alan Redfern and Martin Hunter (1999), Law and Practice of International Commercial Arbitration, $3^{\text {rd }}$ ed., (London: Sweet and Maxwell), at 10-09. (Hereinafter referred to as 'Redfern and Hunter').

${ }^{5}$ See also ibid.

${ }^{6}$ Ibid.

${ }^{7}$ Ibid.

${ }^{8}$ Ibid.

${ }^{9}$ Ibid.
} 
the courts of the state concerned, whereas enforcement is an undertaking by a state to enforce foreign arbitral awards, in accordance with its local procedural rules.

The word 'recognition' is hardly used in the Ethiopian laws in this context. ${ }^{10}$ However, for domestic arbitral awards, an equivalent term "homologation" is employed under Art. 319(2) of the Civil Procedure Code (hereafter CPC). ${ }^{11}$ For a purely domestic judgment, the test as to whether that judgment has a res judicata effect would solely rest on Art. 5. ${ }^{12}$ However, for international policy reasons, the test whether a foreign judgment or arbitral award has a res judicata effect needs to pass the litmus paper test provided under Arts. 458 and 461of CPC respectively.

Art. 461 of CPC provides:

(1) Foreign arbitral awards may not be enforced in Ethiopia unless:(a) Reciprocity is ensured as provided for by Art.458 (a); (b) The award has been made following a regular arbitration agreement or other legal act in_[sic][in accordance with the law of] the country where it was made; (c) The parties have had equal rights in appointing the arbitrators and they have been summoned to attend the proceedings; (d) The arbitration tribunal was regularly constituted; and (e) The award does not relate to matters which under the provisions of Ethiopian laws could not be submitted to arbitration or is not contrary to public order or morals; and, (f) The award is of such nature as to be enforceable on the condition laid down in Ethiopian laws;

(2) The provisions of the preceding Articles shall apply by analogy when the enforcement of a foreign award is sought.

Thus, if the foreign arbitral award for which 'recognition' or 'recognition and enforcement' is being sought satisfies the requirements enumerated under Art. 461(1)(a) through (f) cum Art. 461(2) of CPC, it can have a res judicata effect in Ethiopia. In other words, the foreign arbitral award will have legal force and binding effect in Ethiopian courts and cannot be subject of a new litigation.

${ }^{10}$ The phrase 'recognition and enforcement of arbitral award' is preferable in international arbitrations (including the awards which only 'recognition' is sought for); in our case, as 'enforcement' should necessarily be preceded by 'recognition', the issue of the absence of the latter word remains mere academic.

11 Civil Procedure Code of Ethiopia of 1965 (Hereinafter referred to as 'CPC'). The Federal and States' courts apply their own respective procedural rules, although thus far all remain significantly loyal to the CPC with some minor improvements to the part of the CPC that deals with court jurisdiction.

12 Inter-State recognition and enforcement of judgments and arbitral awards under the Ethiopian federal system may take a different course. As this is largely uncharted territory in under Ethiopian law, the scope of this article is limited to the enforcement proceedings involving foreign arbitral awards. 


\section{3- Nationality of Arbitral Awards}

Art. 3 of CPC defines a 'foreign court' to mean a court situated outside Ethiopia. A 'foreign judgment' is as well defined to mean the judgment of a foreign court. However, 'foreign arbitral awards' are not supplied with a definition in our laws. The question is then, when is an arbitral award said to be 'foreign'?

This is an issue of essential importance because the whole issue of recognition and enforcement, from its inception, centers on whether an award is national or foreign. In a domestic arbitral award, the losing party (award debtor) has two options if he/she is not satisfied with the award; they are the option to appeal against the award or to apply for an order towards setting aside the award. In Ethiopia, for instance, whenever the award is believed, by the awarddebtor, to have been tainted with the defects specified under Art.351 of CPC, the former is resorted to. Whenever the award is believed to have been rendered with the defects specified under Art.356 of CPC, the latter would be resorted to pursuant to Art. 355 of CPC.

Despite the importance of distinguishing between a domestic and foreign arbitral award, there is yet no legal provision to this effect under Ethiopian law. In such a case, it would have been helpful to resort to court decisions on the matter. Unfortunately, the practice does not seem to offer any help in this regard. For example, Art I (1) of the New York Convention (1958) on the Recognition and Enforcement of foreign Arbitral Awards provides the following:

This Convention shall apply to the recognition and enforcement of arbitral awards made in the territory of a state other than the state where the recognition and enforcement of such awards are sought... it shall also apply to arbitral awards not considered as domestic awards in the state where their recognition and enforcement are sought

According to the Convention, an arbitral award is foreign if it is made outside of the territory of the state where the recognition and enforcement of such award is sought. The Convention also recognizes that an arbitral award may be foreign although it is made in the territory where recognition and enforcement of the award is sought. Thus, the following appear to be the means of determining the nationality of an arbitral award:

- $\quad$ the place of rendition of the award;

- the law applicable to the arbitration procedure (i.e. an arbitral award is considered foreign if it has been rendered according to foreign procedural law);

- $\quad$ the place of the proceedings and the nationality of the arbitrators; or,

- the substantive law which has been applied.

If an award has been rendered under foreign substantive law, it may be considered foreign. A foreign award may also be defined as an award which is 
decided by a tribunal outside of the state in which recognition and enforcement is sought.

In modern arbitration laws, states provide for methods of distinguishing between foreign and national awards. In Ethiopia, we do not find such provisions. As will be shown below, however, it is essential both for the award debtor and creditor to clearly differentiate between the two. The legal remedies to be resorted to differ in differ in the two cases. In the absence of legally binding provisions to this effect, therefore, our courts need to resort to one or more of the above-mentioned criteria for determining the nationality of an arbitral award.

\section{Procedures for the Enforcement of Foreign Arbitral Awards}

In the main, the conditions for the recognition and enforcement of foreign arbitral awards in Ethiopia are provided for under Art. 461 of CPC. Apart from that, however, Art. 461(2) of the CPC makes a reference to the applicability of the provisions pertaining to the enforcement of foreign judgments. Hence the provisions governing the enforcement of foreign judgments also apply by analogy when the enforcement of a foreign award is sought. Thus, Art. 461(2) of CPC is an important provision forging a necessary nexus between the enforcement of foreign judgments, on the one hand, and the enforcement of foreign arbitral awards, on the other.

Proclamation No.25/1996 ${ }^{13}$ states that the Federal High Court is vested with the first instance jurisdiction over the 'application regarding the enforcement of foreign judgments or decisions'. ${ }^{14}$ It is not clear whether the provision is advertently formulated so as to exclude foreign arbitral awards from its ambit. Moreover, it is not clear why the Proclamation considers the enforcement of foreign judgments to be outside the scope of private international law.

In the Ethiopian legal discourse (academic and judicial practice), private international law (PIL) rules comprise three major parts, i.e., judicial jurisdiction, choice of law (conflict of law rules), and proceedings for the recognition and enforcement of foreign judgments and foreign arbitral awards. It is to be noted, therefore, that matters involving the recognition and enforcement of foreign judgments and decisions are part of the domain of private international law. ${ }^{15}$ For some unknown but, according to this author,

13 The Federal Courts Proclamation No.25/1996.

${ }^{14}$ Ibid, Art.11(2)(c).

${ }^{15}$ This does not mean, however, that the issue is not controversial. Nor does it mean that it does not differ from a legal system to another. For example, in France, private international law covers conflict of laws (i.e., choice of law), jurisdictional conflicts 
unjustified reason, ${ }^{16}$ the drafters have set out disparate provisions to separately deal with the 'enforcement of foreign judgments' under Art.11(2)(c) and cases regarding private international law under Art. 11(2)(c) of Proclamation No.25/1996. In both cases, the power to hear cases regarding 'private international law' and 'applications regarding the enforcement of foreign judgments or decisions' are vested in the Federal High Court's first instance jurisdiction.

It has been the tradition in the Ethiopian legal system that the recognition and enforcement of foreign arbitral awards can be subsumed under the umbrella of private international law. The appropriate court that has jurisdiction to decide on the application for the recognition and enforcement of foreign arbitral awards is the Federal High Court as per Art. 11(2)( c) of Proclamation No.25/1996.

That aside, an application for the enforcement of a foreign judgment must be in writing. ${ }^{17}$ Furthermore, the application must be accompanied by "a certified copy of the judgment to be executed; and a certificate signed by the President or the Registrar of the court having given judgment to the effect that such judgment is final and enforceable”. ${ }^{18}$

By virtue of Art. 461(2), this requirement is also applicable for the recognition and enforcement of foreign arbitral awards. The UNCITRAL Model Law on International Commercial Arbitration (1985) ${ }^{19}$ provides that the party applying for the enforcement of a foreign award must supply the 'duly

(i.e., jurisdiction and the recognition and enforcement of judgments), nationality law and the status of foreigners. In Germany, it covers only choice of law; jurisdiction and the recognition and enforcement of judgments fall under 'international civil procedure law'. In the United States and England, the usual nomenclature is 'conflict of laws' and covers the jurisdiction, choice of law, and the recognition and enforcement of judgments. See Trevor Hartley (2009), International Commercial Litigation: Text, Cases and Materials on Private International Law, (Cambridge: CUP), p.4. For more on the French PIL, see also Brice Dickson (1994), Introduction to French Law, (London: Longman Group Ltd), chapter 14, pp.238-252.

16 Pursuant to the House of the Federation's decision on June 07, 2010 to communitarize PIL rules and arbitration laws, PIL rules will cover choice of law, jurisdiction, and the recognition and enforcement of judgments. It should be noted that the recognition and enforcement of foreign arbitral awards is to be covered under the arbitration laws. See House of the Federation, Research documents on the process of Communitarization (2009), (unpublished), (On file with the Author).

${ }^{17}$ Art.457 of CPC.

${ }^{18}$ Ibid.

${ }^{19}$ Chapter viii, Art.35(2) of the UNCITRAL Model Law on International Commercial Arbitration of 1985. The full text of the UNCITRAL Model Law is available at $<$ www.uncitral.org/> (Last visited on January 10, 2011). 
authenticated original award or a duly certified copy of it', and the original arbitration agreement or a duly certified copy of it. Moreover, it provides that if the award or agreement is not made in the official language of the state where enforcement is sought, the party must supply a duly certified translation of it into such language.

Similar requirements are set forth in the United Nations Convention on the Recognition and Enforcement of foreign Arbitral Awards (New York Convention) (1958). ${ }^{20}$ The New York Convention further requires that the translation must be 'certified by an official or sworn translator or by a diplomatic or consular agent'. ${ }^{21}$ Thus, Art. 457 of CPC appears less stringent than what is required by the instrument setting forth the minimum international standards. The practice has, however, evolved in tune with what the New York Convention has set forth. Amharic is the working language ${ }^{22}$ of the Federal Courts. Thus, an application for the enforcement of foreign judgments submitted to the Federal Courts is required to be translated into Amharic. Moreover, the current judicial practice requires foreign judgment (that is submitted to an Ethiopian court for recognition and enforcement) to be authenticated by the Ethiopian consulate in the country in which the judgment was pronounced. ${ }^{23}$ These requirements equally apply in cases of foreign arbitral awards.

To sum up, an application for the recognition and enforcement of a foreign arbitral award is made to the Federal High Court (or to the Supreme Court of any State which exercises the Federal High Court's jurisdiction by delegation) by the winning party (award-creditor). The award-creditor has to provide (a) the duly authenticated original award or a duly certified copy of it, (b) the original arbitration agreement or a duly certified copy of it, and (c) a duly authenticated translation of it into Amharic language. ${ }^{24}$

${ }^{20}$ Art. IV(1) and (2) of United Nations Convention on the Recognition and Enforcement of foreign Arbitral Awards (New York Convention) (1958). The full text of the New York Convention is available at <www.uncitral.org/> (Last visited on January 10, 2011).

${ }^{21}$ Ibid, Art. IV(2).

${ }^{22}$ See Art.5 of the 'Constitution of the Federal Democratic Republic of Ethiopia Proclamation No.1/1995', Aug.21, 1995. (Hereinafter referred to as 'The Federal Constitution'). See also Art.25 of the Federal Courts Proclamation No.25.1996, supra note 1.

${ }^{23}$ Ibrahim Idris Ibrahim (1999), 'Ethiopian Law of Execution of Foreign Judgments', Journal of Ethiopian Law, Vol. XIX, p.23.

${ }^{24}$ It is noteworthy that if the award-creditor is making the application to the courts of one or more of the Federated states, the award should be translated to the working language of the state of the seized court. 
The court is, then, required to enable the party against whom the award is sought to be enforced to make his representations of the case ${ }^{25}$ within the time fixed by the court. ${ }^{26}$ The Court is empowered to decide whether or not pleadings may be submitted, ${ }^{27}$ and in case of doubt may suspend its decision on the application until all doubtful points have been resolved. ${ }^{28}$ The decision is to be made on the basis of the application unless for some special reason to be recorded, the court decides to hold a hearing. ${ }^{29}$ The court may also award costs. ${ }^{30}$ If the application is granted, the award is enforced as if it had been given by an Ethiopian court. ${ }^{31}$

\section{Validity of the Arbitration Agreements}

Art. 461(1)(b) of CPC provides that foreign arbitral awards can be enforced only if they are made based on a regular arbitration agreement or in accordance with the law of the country where they are made. Let us pose the following questions to elaborate the conditions enshrined in the aforementioned provision. Firstly, what does a 'regular arbitration agreement' mean? Secondly, what is it meant by the phrase 'in accordance with the law of the country where it was made'? [Emphasis supplied]. Finally, what is it meant by 'the country where it was made'?

\section{1- Regular Arbitration Agreement}

The Civil Code and the Civil Procedure Code have consistently used the terms 'arbitral submission' to mean arbitration agreement although they signify different kinds of arbitration agreements. In modern arbitration laws, arbitration submission would not include arbitration clauses. An arbitration agreement basically means two things: arbitral submission and arbitration clause. In other words, an arbitration clause refers to the arbitration agreement which is incorporated in the main contract signed between the parties. On the other hand, an arbitral submission refers to an arbitration agreement which parties may make at the time when a dispute arises in the event that they have not already stipulated for an arbitration clause in the main contract out of which the dispute has arisen.

\footnotetext{
${ }^{25}$ It is this opportunity that the award-debtor should seize to adduce his available defenses against the enforceability of the arbitral award in Ethiopia.

${ }^{26}$ Art. 459(1) of CPC.

${ }^{27}$ Ibid Art.459(2).

${ }^{28}$ Ibid Art.459(3).

${ }^{29}$ Ibid Art.460(1).

${ }^{30}$ Ibid Art.460(2).

${ }^{31}$ Ibid Art.461(3).
} 
However, the word 'regular' in this context does not seem to be clear. A regular arbitration agreement is meant or, at least, includes an arbitration agreement concluded in accordance with the law (or valid arbitration agreement). An issue arises whether this includes arbitration agreement concluded on the basis of customary rules or usages. The author is of the view that, as long as these customary rules or usages do not contradict with the mandatory arbitration rules of the country where the award was made, a regular arbitration agreement includes such agreements as are concluded on the basis of any customary rules or usages. Thus, a regular arbitration agreement should be interpreted to mean an arbitration agreement that does not violate the mandatory rules (or the public policy rules) in the country where it was made.

Needless to mention, arbitration agreement is a contract to submit existing or future disputes to arbitration for settlement. Thus, the arbitration agreement is governed by the basic principles of contract law. In Ethiopia, for instance, an arbitration agreement is not only subject to the special provisions governing arbitration agreements $^{32}$ but also to the general provisions on contracts. ${ }^{33}$

Thus, a valid arbitration agreement made or concluded in Ethiopia must pass, inter alia, the test under Art.1678 of the Civil Code of Ethiopia which provides the following:

"No valid contract shall exist unless:

(a) The parties are capable of contracting and give their consent sustainable at law:

(b) The object of the contract is sufficiently defined and is possible and lawful:

(c) The contract is made in the form prescribed by law, if any.”

For an arbitral award made in Ethiopia to be enforced in another country, the latter's courts should make sure that, inter alia, the parties to the arbitration agreement are capable of concluding the arbitration agreement and that the consent of one of the parties was not vitiated by mistake (of a fundamental and decisive nature), deceit, duress, lesion (unconcionability) or illicit cause (if the purpose in view is discernible from or denoted in the contract documents). Furthermore, the courts should make sure that the arbitration agreement was made in accord with Art. 3326(2) of the Civil Code, i.e., it must have been drawn up in the form required by law for disposing without consideration of the right to which it relates. It should also be noted that the arbitration agreement must be in writing. ${ }^{34}$ Likewise, Ethiopian courts cannot enforce an arbitral

32 Art.3325-3346 of the 'Civil Code Proclamation No. 165 of 1960', May 5, 1960.

(Hereinafter referred to as 'CC'). The existing Ethiopian Arbitration laws also

include Arts.315-319, 350-357 of CPC.

${ }^{33}$ See Arts.1675-2026 of CC.

${ }^{34}$ Art.315(1) of CPC. 
award that is a result of defective arbitration agreement in the country in which it is made.

\section{2- Foreign award made in accordance with the law of the country where the award is made}

Similar requirements are laid down under the New York Convention ${ }^{35}$, and under the UNCITRAL Model Law. ${ }^{36}$ However, the question as to where an award is deemed to have been made is relevant. Some argue that where an award states that it is dated and signed in a particular place, then, that is considered the place where it has been made. ${ }^{37}$ However, in an international commercial arbitration, with a tribunal of three arbitrators, the award in its final form may be signed in three different countries, each member of the tribunal adding his or her signature in turn. ${ }^{38}$

Some institutional arbitration rules and some national laws deal expressly with the place in which an award is 'made'. ${ }^{39}$ The International Court of Arbitration (ICA) of the International Chamber of Commerce (ICC) Arbitration rules provide that an award is deemed to have been made at the place (or seat) of the arbitration and on the date stated therein. ${ }^{40}$ The UNCITRAL Model Law also provides that the award is deemed to have been made at the place of arbitration. ${ }^{41}$ Thus, the general trend seems to suggest that the seat of arbitration is the place where the award is deemed to have been made.

\section{3- Arbitrability}

The fulfillment of the requirement of arbitrability means that the subject matter that is in dispute must be capable of settlement by arbitration. If the dispute submitted to arbitration by the parties is not arbitrable in the country where the award is made, or according to the law to which they subjected it (lex electionis), the award may face the risk of being set aside.

The Ethiopian courts may examine that the arbitration agreement relates to arbitrable matters in the country where the award is made. It is not, however, clear whether the courts should further probe into the law to which the parties might have subjected it (i.e., lex electionis), if any, in an attempt to verify the arbitrability of the subject matter. It is, thus, good to see the difference between

\footnotetext{
35 Art.V(1)(a).

${ }^{36}$ Art.36(1)(a)(i).

${ }^{37}$ Redfern and Hunter, supra note 4, at 2-15.

38 Ibid.

${ }^{39}$ Ibid, at 2-14.

${ }^{40}$ Ibid.

${ }^{41}$ Ibid.
} 
Art. 461(1)(b) and Art. 461(1)(e) of CPC. These provisions are comparable with Art.V(1)(a) and Art.V(2)(a) of the New York Convention respectively.

If the arbitration agreement is aimed at settling a dispute which is not arbitrable, such an arbitral award will be invalid in a purely domestic arbitration agreement unless national courts give it effect. In an international commercial arbitration, however, the following line of argument by Arfazadeh should be noted.

As a general rule, an award [...] rendered in violation of the rules on arbitrability in force at the place of arbitration is open to challenge before the courts of that country;... if the award has survived the challenge at the place of arbitration, then the foreign enforcement courts should simply dismiss the defense. If the resisting party has failed to appeal and challenge the award, enforcement courts may reasonably conclude that the petitioner has failed to prove that non-arbitrability at the seat of arbitration would be a course of the nullity of the arbitration clause... ${ }^{42}$

This line of argument emanates from the belief that the validity of the arbitration agreement and its arbitrability per se are distinctly governed. The validity of the arbitration agreement is governed by the ordinary principles of contract law whereas arbitrability is connected with the statutory jurisdiction of courts, the public administration of justice and the organization of the judiciary. ${ }^{43}$ It is also submitted that the necessary prerequisite for determining non-arbitrability is the existence of a rule that establishes the mandatory jurisdiction of a state court to the exclusion of arbitration. ${ }^{44}$ Thus, to identify possible restrictions upon arbitrability, attention needs to be focused first on the jurisdiction of the courts. As this is primarily the function of the courts in the rendering country, courts in the enforcing country would ease their scrutiny on the arbitrability of the subject-matter based on the laws in the rendering country.

Hence, Ethiopian courts should not worry whether or not the dispute that the award purports to have settled is arbitrable in the country where the award was made. It should, therefore, be noted that examining the issue of arbitrability by reference to foreign standards of arbitrability rather than the law of the forum, is quite unwarranted in the context of current international arbitration law and practice. $^{45}$

This line of argument, the author holds, serves our courts with four major purposes: (i) it greatly simplifies the intricacies surrounding the arbitrability and non-arbitrability issues in those countries in which the foreign arbitral award is

\footnotetext{
${ }^{42}$ H. Arfazadeh (2001) 'Arbitrability under the New York Convention: The lex fori Revisited’, Arbitration International, Vol.17, No.1, p.86.

${ }^{43}$ Ibid, p.80.

${ }^{44}$ Ibid, p.77.

${ }^{45}$ Ibid.
} 
made; (ii) our courts should not give a refuge to an award-debtor where not only it knowingly agreed to arbitrate on the matter but also failed to challenge it in the courts where the award is made; (iii) it is in a way encouraging international commercial arbitration and respecting the parties' private agreements; and (iv) by taking the order of exequatur given by a court in the rendering country, as required under Art.457(b) of CPC, as the conclusive evidence of the arbitrability of the subject matter, the cherished objective of according arbitral awards 'finality' can be enhanced. By so doing, Ethiopia would be considered as an arbitration-friendly country and capable of attracting foreign investment.

\section{Equal Treatment of the Parties and Regular Constitution of the Arbitral Tribunal}

\section{1- Equal Treatment of the Parties}

The idea that the parties to arbitration should be treated equally throughout the proceeding is the pillar for according an arbitral proceeding the status that it currently enjoys. Indeed, arbitration is predicated on the two minimum standards of natural justice tenets: audita alteram partem and non judex in causa sua.

Art. 461(1)(c) of CPC states that the parties must have had equal rights in appointing the arbitrators and that they have been summoned to attend the proceedings. In Ethiopia, it is established that the parties should have equal rights in appointing the arbitrators. It clearly states that " $t]$ he arbitral submission shall not be valid where it places one of the parties in a privileged position as regards the appointment of the arbitrator". ${ }^{46}$

An arbitral proceeding can be valid only if both the parties to the arbitration are given proper notice in respect of the arbitral proceeding. It is, therefore, essential for the court (in ensuring whether due process was followed) to enable both parties to fully participate in the arbitral preceding. The court is, thus, required to examine, inter alia, that: ${ }^{47}$ (i) the award debtor had been properly represented in the arbitral proceeding; (ii) the right of defense is complied with that the award debtor was enabled to submit his defense and had access to the opponent's documents; and, (iii) all the claims in respect of which the foreign award was passed had been properly notified to the party against whom a decision was given.

Of great import here is that our courts should not grant permission to enforce a foreign arbitral award simply because proper summons have been served in

\footnotetext{
${ }^{46}$ Art.3335 of the CC.

${ }^{47}$ ITC/UNCTAD/WTO (2001), 'Arbitration and Alternative Dispute Resolution: How to Settle International Business Disputes’, Trade Law Series, Geneva, p.126.
} 
accordance with the Civil Procedure Code of Ethiopia. It must see into it that the parties had been properly and duly given the summons in accordance with the procedures drawn up by the law of the state in which that award had been delivered and that the procedures (applied to the servicing of the summons) according to that law did not conflict with public order considerations in the country in which it has to be enforced, in this case, Ethiopia.

\section{2- Regular Constitution of the Arbitral Tribunal}

Art. 461(1) (d) of CPC states that, for a foreign arbitral award to be enforced in Ethiopia, one of the conditions is that the arbitral tribunal that made the award must have been regularly constituted. No doubt, arbitral tribunal refers to a sole arbitrator or a panel of arbitrators sitting to decide the dispute. In Ethiopia, one or several arbitrators can be appointed. The term 'several' under Article 3331 (2) needs to be read in conjunction with Article 3332 which requires the appointment of another arbitrator where there is an even number of arbitrators. The combined reading of Arts. 3331 and 3332 of the Civil Code thus excludes an even-numbered arbitration. ${ }^{48}$ Where the lex arbitri (or in the event of choice of a foreign procedural law, this procedural law and the mandatory arbitration rules of the lex loci arbitri) prohibits the constitution of an arbitral tribunal by an even number of arbitrators; and an arbitral tribunal which does not meet this requirement is not legally or regularly constituted.

In the Ethiopian case, therefore, the use of two arbitrators sitting to hear a case with a third arbitrator (the so-called umpire) cannot be considered as valid arbitration agreement. The use of an umpire, thus, voids the arbitration agreement for failing to have an odd numbered arbitral tribunal. ${ }^{49}$

${ }^{48}$ For more on this, see Zekarias Keneaa (2007), 'Formation of Arbitral Tribunals and Disqualification and Removal of Arbitrators under Ethiopian Laws', Journal of Ethiopian Law, Vol.XXI, p.150.

${ }^{49}$ Despite the poor draftsmanship of the arbitration clauses in many of the standard forms of insurance contracts and performance bonds that are currently in use in Ethiopia, the fact that the clauses require of the 'umpire' to sit with the two arbitrators and decide together offers life to the arbitration clause. Contracting parties should be well aware of the difference between a presiding arbitrator and an umpire. The latter is required to act only where the two appointed arbitrators disagree, upon which he takes over as sole arbitrator; depending on the parties agreement, he may or may not attend the hearing with the arbitrators. In our case, however, the arbitral tribunal consisting of odd-numbered arbitrators must act together and decide together; otherwise, either party may invoke Art. 356(b) of CPC for a set aside recourse on the basis of failure of the arbitrators to act together. 


\section{Finality and Enforceability of the Award}

\section{1- Finality}

The Civil Procedure Code does not have express or implied definition pertaining to the concept of 'finality'. Nor does it feature in Art. 461 as a requirement for the determination of recognition and enforcement of a foreign arbitral award as it does in the case of foreign judgments (Art. 458(d) cum 457(b)). Nevertheless, finality is a concept of great import in the case of the recognition and enforcement of foreign judgments and foreign arbitral awards alike. ${ }^{36}$ Thus, we can conclude that, by virtue of Art. 461(2), Art. 457(b) applies equally in the process of having an arbitral award recognized and enforced.

Finality refers to the situation when an arbitral award has acquired the force of res judicata in the sense that no ordinary appeal, set aside procedure, or other recourse (as may be provided for by the lex loci arbitri or by the lex electionis) against it is possible. An arbitral award having acquired the force of res judicata simply means that an arbitral award "already decided between the same parties or their privies on the same question by a legally constituted [arbitral tribunal] having jurisdiction is conclusive between the parties, and the issues cannot be raised again". ${ }^{50}$ Although the concept of res judicata, per se, is universally recognized, its definition may not be uniform across the board. Thus, the concept of 'finality' as used in this context must be distinguished from the concept of res judicata under Art. 5. They are two separate and independent conditions that a foreign arbitral award should satisfy for it to be recognized and enforced in Ethiopia. The concept of finality is seen in light of the res judicata rules of the legal system of which the arbitral award is national. Thus, the Ethiopian courts cannot recognize and enforce a foreign arbitral award that does satisfy the 'res judicata' test, under Art. 5, which, however, fails to satisfy the 'finality' test of the legal system of which the arbitral award is a national or vice versa.

The Ethiopian court, seized to decide on the application, would in our case see to it that all recourses available in the lex loci arbitri are exhausted. These recourses are often appeal, ${ }^{51}$ and set aside proceedings. ${ }^{52}$ However, if the award-debtor did not, for instance, appeal or apply for the set aside proceedings within the prescribed time frame in the locus arbitri, then, it is considered that

\footnotetext{
${ }^{50}$ Margaret Moses (2008), The Principles and Practice of International Commercial Arbitration, CUP, p.188

${ }^{51}$ Art.350-351 of CPC.

${ }^{52}$ Art.355-356 of CPC.
} 
those recourses are exhausted. ${ }^{53}$ It should also be kept in mind that a right of appeal against arbitral awards can be waived in Ethiopia on the condition that it is made with full knowledge of the circumstances. ${ }^{54}$

Therefore, assuming that both the above-mentioned recourses are exhausted, the arbitral award is, then, considered to have passed the test of finality in Ethiopia. However, this Ethiopian finality test does not automatically grant the award a res judicata effect in the rendering country; the award must pass the test of res judicata in the rendering country. ${ }^{55}$ Thus, it is unfortunate that the awardcreditor has to obtain the declaration of the 'finality' of the arbitral award both in the rendering country and in the enforcing country. This is the process of obtaining double exequatur or double scrutiny. ${ }^{56}$ By virtue of Art. 461(2) cum Art. 457(b) of the CPC, this process of obtaining double exequatur is required of a foreign arbitral award to enforce it in Ethiopia. Looked at from the perspectives of the award-creditor, the requirement of double exequatur is a cumbersome exercise as well as an obstacle from potentially taking advantage of the nascent bizarre possibility of enforcing 'annulled' arbitral awards by some countries. ${ }^{57}$

\section{2- Enforceable Nature of the Award}

Art. 461(1)(f) requires that the award be of an enforceable nature on the condition laid down in Ethiopian laws. What does it mean by "an award of enforceable nature"? What does 'the condition laid down in Ethiopian laws' refer to? To determine the significance of the term 'enforceable', let us consider what the nature of an award may look like. A final award may come up with

${ }^{53}$ The prescribed timeframe for an appeal and set aside proceedings is 60 days and 30 days of the making of the award respectively. See Arts. 323(2) and 355(2) of CPC.

${ }^{54}$ Art. 350(2) of CPC.

${ }^{55}$ This is why the award-creditor has to produce a certificate signed by the President or the Registrar of the court of the rendering country to the effect that the award is final and enforceable. This is what is termed as the order of 'exequatur'. This is cumbersome to the award-creditor because not only does it have to authenticate the arbitral award and certify the copies thereof with a notary but also seek the order of 'exequatur' from the courts in the rendering country.

${ }^{56}$ The New York Convention has got rid of the double exequatur and the word 'final' or 'finality' in the enforcement proceeding as the latter also led to problems. See Hans Harnik (1983), 'Recognition and Enforcement of Foreign Arbitral Awards', The American Journal of Comparative Law, vol.31, p.708.

${ }^{57}$ France and USA are the two leading countries on this front. For more on this, See Gary Sampliner (1997), 'Enforcement of Nullified Foreign Arbitral Awards: Chromalloy Revisited', Journal of International Arbitration, Vol.14, No.3, pp.141165; Peter Gillies (2005), 'Enforcement of International Arbitral Awards - The New York Convention’, Int'l Trade and Bus. Law Review, Vol.9, pp.9-43. 
one or more of the following remedies: ${ }^{58}$ monetary compensation, punitive damages or exemplary damages, specific performance, injunctive relief, declaratory relief, interest, costs, etc.

Should Ethiopia, for example, enforce a foreign arbitral award granting the award-creditor exemplary damages and/or punitive damages? As Ethiopia does not itself recognize such a remedy, there is no possibility to enforce (execute) such remedies. Can Ethiopia also enforce an arbitral award that imposes forced [specific] performance against the award-debtor? The answer is possibly 'yes' provided that the conditions for executing it are available in the Ethiopian laws. The conditions are as laid down under Art.1776 of the Civil Code that "Specific performance of a contract shall not be ordered unless it is of special interest to the party requiring it and the contract can be enforced without affecting the personal liberty of the debtor".

From the reading of the above legal provision, Ethiopian courts should not enforce a foreign award granting specific performance if it affects the personal liberty of the award-debtor. Moreover, in the event that a dispute arising from an administrative contract is resolved by means of arbitration, Ethiopian courts cannot recognize and enforce an award granting specific performance ${ }^{59}$ against an administrative authority. From this we can understand that Art. 461(1) (f) of the CPC enjoins the Ethiopian courts to be prospectively far-sighted, unlike the other sub-articles that require the courts to retroactively examine the circumstances surrounding the foreign arbitral award. In other words, the aforementioned provision is meant to set up an 'early warning system' to put the courts on guard to the question (before the permission to enforcement is granted).

\section{Reciprocity Requirement}

\section{1- The concept}

The other important but controversial criterion for the recognition and enforcement of foreign arbitral awards is that, by virtue of Art. 461(1)(a) of the

${ }^{58}$ Redfern and Hunter, supra note 4, p.361.

${ }^{59}$ See the non-applicability of specific performance remedies against an administrative authority under Art. 3194 of the Civil Code, a provision under Title XIX of the Civil Code (Arts.3131-3306 of CC) that deals with Administrative Contracts. In this regard, even for pecuniary awards, the court should be cognizant of the domestic rules, if any, on sovereign immunity against execution of state property or accounts when and if the award-debtor is the State, State entities, State-owned-Enterprises (SOEs) or Business Organizations (wherein the State is the majority or minority share holder). 
CPC, reciprocity should be ensured as provided for by Art. 458(a), ${ }^{60}$ If the courts of the rendering country refuse to execute Ethiopian judgments, the Ethiopian courts must, in turn, refuse to execute theirs. As Ibrahim Idris noted, "it has retaliation against a state as its basis, but which may simultaneously victimize innocent individuals ... because of the policies of the country whose court has rendered the judgment”. 61

Despite this, however, many states uphold the principle. On the other hand, the recent trend, especially with regards to recognition and enforcement of foreign arbitral awards seems to relax or completely reject the doctrine of reciprocity. As Amazu Asouzu, noted, "it is good news that many member states to the New York Convention are reconsidering the reciprocity requirement." ${ }^{, 62}$ It is advised that the Ethiopian courts should take note of the fact that there are 16 contracting states (to the New York Convention) in Africa without the reciprocity requirement. ${ }^{63}$ The UNCITRAL Model Law also rejects the reciprocity requirement, and many states are adopting it into their arbitration laws. Therefore, a state adopting the Model Law is assumed to have foregone the reciprocity requirement unless it maintains it by modifying the Model Law. In fact, in matters of international commercial arbitration, the reciprocity prerequisite is gradually losing ground as states continue to join the New York Convention countries and/or adopting and adapting the UNCITRAL Model Law.

Despite the afore-mentioned trend, however, the doctrine of reciprocity, as it stands now, continues to gain currency in Ethiopia until it becomes a party to the New York Convention without the reciprocity reservation, or adapt the UNCITRAL Model Law, or revises Art. 461 of the Civil Procedure Code.

Furthermore, due consideration ought to be given to the grounds which gave rise to the reciprocity doctrine. It is stated that it is:

'.. necessitated by the absence of international sanction against states that refuse to enforce foreign judgments. It is a self-help measure designed to ensure respect for a state's judgment by another state. Pursuant to this principle, a state that has

${ }^{60}$ Art. 458(a) reads: "Permission to execute a foreign judgment shall not be granted unless (...) the execution of Ethiopian judgments is allowed in the country in which the judgment to be executed was given.”

${ }^{61}$ Ibrahim Idris Ibrahim, supra note 23, p.24

62 Amouzu A. Asouzu (1999), 'African States and the Enforcement of Arbitral Awards: Some Key Issues', Arbitration International, Vol.15(1), p.40; these are: Benin, Burkina Faso, Cameroon, Cote d'Ivore, Djibouti, Egypt, Ghana, Guinea, Lesotho, Mali, Mauritania, Mauritius, Niger, Senegal, South Africa and Zimbabwe.

${ }^{63}$ Ibid. 
adapted reciprocity shall refuse to enforce judgments of those states that do not enforce its judgments, ${ }^{64}$

On the part of our courts, however, since the retaliatory action is to be taken on the basis of the existence or non-existence of reciprocity, great care must be taken in establishing it. The question as to when is reciprocity said to exist thus needs utmost prudence.

\section{2- The Existing Conundrum}

Incessant confusion looms large in our courts with regard to the interpretation and application of the principle of reciprocity. In this respect, Ethiopian courts have been giving inconsistent interpretations. ${ }^{65}$ The prominent ones are briefly presented here: ${ }^{66}$

\section{CASE I:}

In the matters of Paulos Papassinous, the Federal Supreme Court's decision was the following:

The only way to prove that another state allows execution of Ethiopian judgments is by showing a treaty of judicial assistance signed between Ethiopia and that state. If such a treaty does not exist, then the requirement of reciprocity is not satisfied. ${ }^{67}$

The decision unduly equates reciprocity with the existence of a treaty of judicial assistance, and this reasoning takes us nowhere! It, in effect, means that Ethiopian courts will have no foreign arbitral award to enforce because Ethiopia has not signed any treaty of judicial assistance concerning the recognition and enforcement of arbitral awards. It is also equally true of foreign judgments, as it will be described below, because Ethiopia has signed such treaty only with the Republic of Djibouti.

${ }^{64}$ Samuel Teshale (2000), 'Reciprocity with Respect to the Enforcement of Foreign Judgments in Ethiopia: A Critique of the [Federal] Supreme Court's Decision in the Paulos Papassinous case' 12 RADIC, p.571.

65 All the decisions that I have produced below to elaborate on the doctrine of reciprocity are given solely in relation to the recognition and enforcement of foreign judgments. The doctrine is, however, equally applicable to the enforcement proceedings of foreign arbitral awards. Thus, the cases help trace the murky trail of incoherent court decisions on the subject.

${ }^{66}$ Translations for all cases are mine.

${ }^{67}$ In the matters of Paulos Papassinous (Federal Supreme Court of Ethiopia, Civil Case No.1769/88), 1996, (unpublished). 


\section{CASE II:}

The Federal High Court's decision (In the matters of Paulos Papassinous) states that "[t]he non-existence of a treaty of judicial assistance is the sole proof requisite to establish the fact that a state does not allow execution of judgments rendered in Ethiopia." ${ }^{68}$ In other words, the Court would not enforce any foreign judgment or arbitral award unless it is accompanied by a treaty of judicial assistance in force between Ethiopia and the rendering country. As there is only one treaty of judicial assistance in force, this decision does not seem to have considered such realities.

\section{CASE III:}

The Federal High Court's decision in Goh-Tsibah Menkreselassie v Dr. Bereket Habte-selassie ${ }^{69}$ reads:

The absence of the treaty of judicial assistance should not limit the rights of private citizens: and that in the absence of an agreement to the contrary between the two states, it would be inappropriate to refuse the enforcement of a foreign judgment simply because there exists no treaty of judicial assistance.

In this case, the Court held that the absence of the treaty of judicial assistance should not limit the rights of private citizens and, that in the absence of an agreement to the contrary between the two states, it would be inappropriate to refuse the enforcement of a foreign judgment simply because there exists no treaty of judicial assistance. This holding takes us nowhere, too! In fact, it would be unlikely for states to enter into an agreement 'promising' each other that they would not enforce each other's judgments or arbitral awards. Therefore, the Court's decision, in effect, means that all foreign judgments or foreign arbitral awards will be recognized and enforced in Ethiopia. No doubt, this is tantamount to rejecting altogether the reciprocity rule in Ethiopia. This cannot be the intention of the legislators.

\section{CASE IV:}

The Federal High Court's decision in Michel Kohler v Derlexia Kenyat held that "[i]f there is no treaty of judicial assistance, proof that a state enforces Ethiopian judgments should be adduced”. ${ }^{70}$ As per the decision, the Court ordered the

${ }^{68}$ In the matters of Paulos Papassinous (Federal High Court of Ethiopia, Civil Case No.1623/80), 1987, (unpublished).

${ }^{69}$ Goh-Tsibah Menkre-Selassie v Dr Bereket Habte-Selassie (Federal High Court of Ethiopia, Civil Case No.85/92), 2001, (unpublished).

${ }^{70}$ Michel Kohler v Derlexia Kenyat (Federal High Court of Ethiopia, Civil Case No.29/90), 1999, (unpublished). 
applicant to adduce proof that the state (in this case USA) enforces Ethiopian judgments.

The applicant cited two decisions of Ethiopian courts, and he claimed that they were recognized and enforced in the United States of America. The Court ordered the Ministry of Foreign Affairs to confirm the information. However, the Ministry could not trace the decisions. The applicant argued that the US Uniform Child Custody Jurisdiction Act (the UCCJA) imposes the obligation on the US courts to recognize and enforce foreign judgments on child custody. This, according to the applicant, conclusively proves that the USA would enforce Ethiopian judgments. Thus, the Court held that child custody decisions given by US courts should be recognized and enforced in Ethiopia as US courts are legally obliged by the Act ${ }^{71}$ to recognize and enforce Ethiopian decisions on child custody.

\section{CASE V:}

In Commercial Bank of Ethiopia v Samson Yimenu et al, the Federal First Instance Court's decision states that "[I]f treaty of judicial assistance exists, [and] if the foreign judgment satisfies the requirements enumerated under Art. 458, it can be allowed to be recognized and enforced". ${ }^{72}$

This case relates to a judgment of a Djiboutian court given in favor of the Commercial Bank of Ethiopia against an Ethiopian who is domiciled in Djibouti. The heirs of the judgment-debtor managed to flee all their assets to Ethiopia. The Commercial Bank of Ethiopia, instead of seeking for the recognition and enforcement of the Djiboutian Court's decision as per Art. 458 of the CPC, instituted a fresh suit against the heirs of the foreign judgmentdebtor in the Federal First Instance Court. The heirs instituted a preliminary objection to the effect that the case has been settled as it has been decided in a

${ }^{71}$ The Act appears to apply only to the US inter-state child custody jurisdictional matters as the definition of "states" which are subjects to the UCCJA include: "any state, territory, or possession of the United States, the Commonwealth of Puerto Rico and the District of Columbia ..." Despite the statutory definitional limitation, there is a growing tendency by some states to extend the applicability of the UCCJA for international circumstances. For more on this, See Christopher L. Blakesley (199798), 'Comparative Ruminations from the Bayou on Child Custody Jurisdiction: The UCCJA, the PKPA, and the Hague Convention on Child Abduction', 58 Louisiana L. $R$ 449; see also William M. Richmond and William L. Reynolds (2002), Understanding Conflict of Laws, $3^{\text {rd }}$ ed., (Toledo: Mathew Bender), pp.421-428 (wherein no mention is made or implied as to the applicability of the Act to international judgments).

${ }^{72}$ Commercial Bank of Ethiopia v Samson Yimenu et al., (Federal First Instance Court of Ethiopia, Civil Case No. 111/93), 2002, (unpublished). 
Djiboutian court that had jurisdiction to hear the case. It was admitted by the litigating parties that the judgment was given, following due process of law, by a court duly established and constituted under the Djiboutian laws.

The Court had to decide whether the case should be litigated all over again. The Court held that Art. 5 of CPC applies to all courts (domestic or foreign) so long as the court (be it domestic or foreign) is legally entitled to dispose of the suit. Furthermore, the Court underscored that the wording 'any court having jurisdiction' used under Art. 5(1) of CPC is meant to include foreign courts. Thus, the Court decided that as the case involved the same parties and cause of action and as the decision was given by a competent Djiboutian court, it satisfies the requirements under Art. 5 of the CPC.

The Federal First Instance Court, thus, went on further to establish whether reciprocity exists between Ethiopia and Djibouti. Having established that reciprocity existed, it finally disposed of the case stating that the judgmentcreditor can enforce the judgment by showing that the remaining requirements under Art. 458 of CPC are satisfied. This is an erroneous interpretation of the doctrine of reciprocity.

\section{CASE VI:}

In Commercial Bank of Ethiopia v Demere Gobena \& Senait Assefa, ${ }^{73}$ the Federal Supreme Court held that "[c]oncerning the enforcement of foreign judgments, neither a treaty nor an established practice exists between the United States and Ethiopia.” This case was an appeal against the decision of the Federal High Court. The lower Court had ruled that the case has definitively been disposed of by the New York State Supreme Court (in the United States) and that the case at hand should be dismissed on the basis of Art.5(1) of the CPC.

However, the Federal Supreme Court, whilst noting that foreign judgments may be enforced on the basis of either treaty or CPC requirements, hastened itself into the conclusion that as there is no treaty and/or established practice between the US and Ethiopia, the judgment-creditor had no option, according to the Court, but litigate the case afresh in the Ethiopian courts. This decision of the Federal Supreme Court seems to be erroneous on two grounds. Firstly, prior to this decision, there was in fact an established practice of recognizing and enforcing each other's decisions. ${ }^{74}$ And, secondly, in matters of private

${ }^{73}$ Civil Appeal No.15908, (2005) (unpublished).

${ }^{74}$ See, for example, Cases III and IV above. It is also good to note that the Ministry of Foreign Affairs (MoFA) in its letter to the Federal High Court had hinted, by which the Federal Supreme Court could also have informed itself, on the existence of such practice between the US and Ethiopia in its response to the lower Court's query as to 
international law, each of the states in the United States should be scrutinized on its own. ${ }^{75}$

\section{3- Cutting the Gordian Knots!}

In order to salvage the situation, therefore, let us examine the modus operandi of the treaty of judicial assistance, on the one hand, and the reciprocity requirement, on the other. A treaty of judicial assistance may include, depending on the extent of the agreement between the two states, enforcement of foreign judgments, foreign arbitral awards, assistance to be provided by a foreign state in procuring evidence, serving summons, etc. In this respect, the Treaty ${ }^{76}$ between the Transitional Government of Ethiopia and the Government of the Republic of Djibouti on Judicial Assistance signed at Addis Ababa on August 2,

whether there existed any treaty of judicial assistance between the two countries. For more on this point, see Zefania Alemu Biks (2005), 'A Critique on the Federal Supreme Court's Decision Concerning the Execution of Foreign Judgments in Ethiopia, Awde Fith (Amharic Newspaper), No.10, April 2005, pp.13-14. In the area of arbitration, the federal courts of the US seem to have passed the test of reciprocity as the US court recognized in 1976 an Ethiopian arbitral award in favor of the then Imperial Ethiopian Government (IEG) against Baruch Foster Corporation (BFC) despite the latter's attempt at frustrating the recognition process by claiming that the President of the Tribunal the late Professor Rene David had a material connection to Ethiopia as he drafted the Ethiopian Civil Code twenty years earlier. The Court rejected the award debtor's argument and decided that it was only an attempt to 'freeze the confirmation proceedings in their tracks and indefinitely postpone judgment'. See Georges R. Delaume (1997), 'Recognition and Enforcement of State Contract Awards in the United States; A Restatement', 91 Am. J. Int'l L.476. For the full text of the award, see EACC (2008), 'Report of Arbitral Awards', Vol.I, p.1-24.

${ }^{75}$ In our case, our courts have to scrutinize each of the States as to how it approaches the doctrine of reciprocity. It can be noted, for example, in Ibrahim Idris Ibrahim, supra note 23, p.19, that the New York and California States of the US do not require reciprocity for the recognition and enforcement of foreign judgments. Also for a brief remark on whether and which State requires the doctrine of reciprocity, see The American Law Institute (2004), International Jurisdiction and Judgments Project (Tentative Draft No.2 (April 13, 2004), pp.89-91. This does not, however, apply to the recognition and enforcement of foreign arbitral awards in which case the US courts apply the New York Convention of 1958 and, whenever it is 'more favorable' to the award-creditor, the American Federal Arbitration Law can be resorted to. For more on this, see Georgios C. Petrochilos (1999), 'Enforcing Awards Annulled in Their State of Origin Under the New York Convention', 48 Int'l and Comp. L. Q., pp.856-888.

${ }^{76}$ A Proclamation to Ratify the Treaty on Judicial Assistance between the Transitional Government of Ethiopia and the Republic of Djibouti, May 31, 1995 (Hereinafter 'The Treaty') (the full text of the Treaty on file with the Author). 
1994 and put in effect on May 31, 1995, includes judicial assistance in matters of enforcement of foreign judgments, procuring evidence, serving summons, etc. From both the literal and purposive readings of the Treaty, the author finds it difficult to assume that reciprocal enforcement of arbitral awards had been part of the bargain in the Treaty. ${ }^{77}$

For the purpose of our discussion here, however, the term treaty of judicial assistance is used to mean a treaty for the enforcement of foreign judgments and/or foreign arbitral awards. It should be clear from the outset, therefore, that if there is a treaty of judicial assistance between two states, then it would be inappropriate to inquire whether reciprocity exists. As noted by Samuel Teshale, "[t]he law has laid down two grounds for execution of foreign judgments in Ethiopia; namely, on the basis of treaty and on the basis of statutory requirements."78 In other words, a foreign judgment or a foreign arbitral award is enforced either in accordance with the treaty provisions or the statutory provisions under Art. 458 or 461 of CPC. Therefore, when the courts are seized with an application for the enforcement of foreign judgments or foreign arbitral awards, the first question to ask is: whether there is a treaty of judicial assistance with the state which gave the judgment or award whose enforcement is sought.

In practice, courts order the Ministry of Foreign Affairs to supply the information on whether a treaty of judicial assistance exists. If the response is in the affirmative, then the next step for the courts is to require its submission to them. To this effect, the courts may have to order once again the Ministry of Foreign Affairs to produce ${ }^{79}$ the said treaty. ${ }^{80}$ Once the treaty itself is presented

${ }^{77}$ The author is of the opinion that an arbitral award rendered in Ethiopia can be homologized into a court judgment and enforced under the Treaty. However, a word of caution is needed here because such act may have the effect of transforming the award into a judgment which may mean that it will henceforth be considered as a judgment.

${ }_{78}^{78}$ Samuel Teshale, supra note 64, p.574.

79 The Ministry of Foreign Affairs is the repository of 'all authentic copies of international treaties and agreements concluded between Ethiopia and other states or international organizations' by virtue of Art.25(7) of the 'Definition of Powers and Duties of the Executive Organs of the FDRE Proclamation No.4/1995.'

80 Ethiopia applies the 'Automatic ad hoc incorporation of the Legislative ad hoc incorporation' modality of implementation of international treaties whereby international treaties signed by the Executive and ratified by the Federal Parliament is given full force and effect by an enabling legislation which consists of a few provisions stating that the treaty to which reference is made has come into force in Ethiopia, without the need to publish the text of the treaty in the Federal Gazette. For 
to it, the court should go through its provisions. This will enable the court to determine on what conditions, under the said Treaty, it should enforce the foreign judgment or foreign arbitral award.

Against this backdrop, we can see the Federal First Instance Court's decision in the case of Commercial Bank of Ethiopia vs Samson Yimenu et al (CASE V). The Court held that if a treaty of judicial assistance exists, then the foreign judgment can be allowed to be recognized and enforced if it satisfies the requirements enumerated under Art. 458. No doubt, if there is a treaty of judicial assistance, reciprocity exists as required under Art. 458(1) of CPC. But assuming that a treaty of judicial assistance exists between the two countries, should the foreign judgment given by the Djiboutian court be required to satisfy the requirements enumerated under Art.458? Should it also satisfy the formality requirements developed as judicial practice, such as consular authentication of the judgment? The Court's affirmative decision seems unequivocal in this regard. The Court errs in its decision because Art. 7 of the Treaty of Judicial Assistance between Ethiopia and Djibouti states that “[c]onsular legalization or any other like formality shall not be required for [...] applications for the execution of judicial decisions."

Equally important is Art.18 of the Treaty which states, "Each contracting state shall, subject to the conditions laid down in the present Treaty, recognize the judicial decision of the other contracting state and shall cause same to be executed in its territory". It is clear from the reading of this provision that the clause "subject to the conditions laid down in the Present Treaty" automatically renders the application of Art. 458 of CPC unnecessary.

One cannot but wonder, then, on what conditions a Djiboutian judgment may be enforced in Ethiopia or the vice versa. Art.19 of the Treaty is worth noting. It reads:

The judicial decisions rendered by the Judicial Authority of one contracting state shall be recognized and executed having the force of law in the territory of the requested state, if it satisfies the following conditions:

- The Judicial decision was given by a Judicial Authority duly established and constituted according to the law of the requesting state;

- The judicial decision does not violate the exclusive jurisdictional competence of the judicial authority of the contracting state in whose territory it is to be executed:

- No judicial decision has been given previously or no case is pending on the same subject matter and between the same parties before a judicial authority of the requested state;

more on the modalities of implementation of international rules, see Antonio Cassese (2005), International Law, $2^{\text {nd }}$ ed., (New York: OUP), pp.220-223 
- The judgment debtor was given the opportunity to appear before, and present his defense to the judicial decision;

- The judicial decision is final and enforceable according to the law of the requesting state.

Moreover, Art. 9 of the Treaty provides that "[t]he contracting state may refuse... applications for the execution of judicial decisions, if it considers that such execution is contrary to its basic legal principles or is prejudicial to its national sovereignty, security, public order or moral.”

How much of the CPC's inconvenient hurdles the Treaty might have cleared away has not yet been scrutinized. Yet, by imposing the applicability of the CPC, the Federal First Instance Court's decision would have resulted in considerable miscarriage of justice. This is, therefore, a vivid evidence to show that a foreign judgment or foreign arbitral award, given in a country with which Ethiopia has signed a treaty of judicial assistance, must be scrutinized in light of the conditions provided for in the treaty itself. In other words, a treaty of judicial assistance or any other international convention of a similar nature may provide for a set of conditions for the enforcement of foreign judgments or foreign arbitral awards. ${ }^{81}$

The other issue that needs to be addressed is what the court should do once it has realized that no treaty of judicial assistance exists between Ethiopia and the rendering country. Art. 458 of CPC governs the rest of foreign judgments, i.e., those that do not invoke a treaty for their enforcement. Likewise, Art. 461 of CPC governs all foreign arbitral awards that do not invoke a treaty for their enforcement.

In scrutinizing the application for the execution of foreign Judgment or foreign arbitral award, therefore, the first question is whether judgments or arbitral awards of Ethiopian courts are enforced in the rendering country. The problem, therefore, is how to prove the existence of reciprocity. It is submitted that the decisions by the Federal Supreme Court and the Federal High Courts in the Paulos Papassinous case that only a treaty of judicial assistance shall prove the existence of reciprocity is erroneous. ${ }^{82}$

The reciprocity rule must be viewed in light of the objective it is intended to serve. It is a mechanism by which a state ensures that the enforcement of its arbitral awards is not rejected without sufficient and justified grounds. Thus, a state refuses to enforce arbitral awards of those states that do not enforce its arbitral awards. As Sedler noted, "in as much as most countries will execute the

${ }^{81}$ See the discussion below on the recognition and enforcement of arbitral awards under a treaty or convention.

${ }^{82}$ See also Samuel Teshale, supra note 64, p.574 
judgment of other countries it should be presumed that any country will execute an Ethiopian judgment unless the contrary is proved". ${ }^{83}$ Similarly, Ibrahim Idris wrote:

A defendant who intends to attack the execution of a foreign judgment, among others, would be expected to plead and prove that the foreign court rendering the judgment in question would refuse to execute a judgment pronounced by an Ethiopian court. Where the Ethiopian court is satisfied by the proof presented by the defendant, the application to have the foreign judgment executed in Ethiopia will not be granted. ${ }^{84}$

Moreover, in light of the fact that many states are dropping the reciprocity requirement with respect to the recognition and enforcement of foreign arbitral awards, due care is necessary not to take a 'retaliatory' action against 'innocent' states that would not hesitate to enforce arbitral awards rendered in Ethiopia. After all, it would not be proper to presume that a state does not enforce Ethiopian arbitral awards until it is proved otherwise.

The reciprocity requirement enables states to punish 'the rogue states' (in matters of international commercial arbitration) that refuse to enforce foreign arbitral awards, and thus, there is no reason why states cannot be presumed 'innocent' until proven otherwise. Unfortunately, the Court took a different approach in the case of Michel Kohler v Derlexia Kenyat (CASE IV) by ordering the applicant (Mrs. Michel Kohler) to prove that US courts enforce Ethiopian judgments.

What would happen if, assuming for a while, the applicant could not prove that? It seems that the Court would deny recognition and enforcement of the judgment. The only option left to the applicant, then, was to produce to the Federal High Court the United States Uniform Child Custody Jurisdiction Act (UCCJA). This case involved a US (Los Angeles) court's judgment on child custody. The ensuing landmark decision by the Federal High Court (CASE IV above) was that:

Since US courts are required to recognize and enforce Ethiopian judgments on child custody by virtue of the Act, Ethiopia cannot refuse to recognize and enforce US court's judgments on child custody given on the basis of the Act.

Samuel Teshale noted that "the jurisprudence of certain state is reflected in both its statutes and judicial practice; both must be adduced to establish whether or not that state allows execution of foreign judgments". ${ }^{85}$ This statement can be used as a stepping stone to suggest that it is the defendant (award-debtor or

\footnotetext{
${ }^{83}$ Robert Allen Sedler (1968), Ethiopian Civil Procedure (Addis Ababa: OUP) , p.394

${ }^{84}$ Ibrahim Idris, supra note 23, p.30

${ }^{85}$ Samuel Teshale, supra note 64, p.574
} 
judgment-debtor) who should prove (on the basis of the statutory law and judicial practices of the rendering country) that the latter's courts do not recognize and enforce Ethiopian judgments in order to successfully forestall the recognition and enforcement of the foreign judgment or foreign arbitral award against it.

This cogent argument also negates the Federal High Court's decision that would otherwise have a far-reaching negative repercussion. This is so because, firstly, it renders foreign judgments or arbitral awards (given in those states that have already rejected the principle of reciprocity) capable of being recognized and enforced in Ethiopia. Thus, this line of argument will accommodate states that do not attach conditions to the recognition and enforcement of foreign judgments $^{86}$ and foreign arbitral awards ${ }^{87}$ on the doctrine of reciprocity. Secondly, it means that arbitral awards made in the states that have become parties to the New York Convention without reciprocity reservation may be recognized and enforced in Ethiopia.

It is submitted that the Treaty of Judicial Assistance signed between Ethiopia and Djibouti cannot be stretched to incorporate arbitral awards. ${ }^{88}$ However, if the Ethiopian courts are seized with an application for the recognition and enforcement of an arbitral award made in Djibouti, Ethiopia should recognize and enforce it as Djibouti is presumed to recognize and enforce Ethiopian arbitral awards owing to its commitment under the New York Convention. This is because Djibouti is a party to the Convention without the reciprocity and commercial reservation. ${ }^{89}$ This means that Djiboutian courts are presumed to recognize and enforce arbitral awards based on the Convention rules irrespective of the fact that the arbitral award is made in one of the contracting states to the Convention.

As part of their commitments in the promotion of unrestrained mobility of arbitral awards, Convention states, by becoming party to the Convention without the reciprocity reservation, not only extend their commitment to apply the Convention rules to the Convention states but also to the Non-convention states.

${ }^{86}$ For example, The Argentine, Brazil, the New York and California states of the US are mentioned in Ibrahim Idris, supra note, 23, p.24

${ }^{87}$ For example, Brazil and The Argentine do not take reciprocity for the recognition and enforcement of arbitral awards. See Earnest Lorenzen (1935), Commercial Arbitration: Enforcement of Foreign Awards', Yale Law Journal, Vol.45, No.1, pp.39-68.

${ }^{88}$ It is pointed out that an Ethiopian arbitral award properly homologized (confirmed in a court judgment) , as per Art.319(2) of CPC, should come to the ambit of the Treaty.

${ }^{89}$ The list of Convention countries is available at <www.uncitral.org/> (Last visited on January 10, 2011) 
Thus, making the latter beneficiaries of a Convention to which they are not parties, regardless of the traditional conception that 'treaties are binding only between the parties thereto'. In effect, such Convention states commit themselves to subscribe to what Lew et $a l^{90}$ call the 'principle of universality' rather than the 'principle of reciprocity'. In other words, such Convention states are constrained from having another set of criteria for the recognition and enforcement of arbitral awards made in the Non-Convention states. Whether the Non-Convention states are legally entitled to invoke such commitment in their favor remains yet to be seen. It can, however, be safely presumed that, unless proven otherwise, the Convention state remains loyal to its commitment under the New York Convention.

In a similar vein, other states that are party to the Convention without declaring the reciprocity requirement should receive similar treatment in Ethiopia. Furthermore, it means that Ethiopia will also enforce arbitral awards made in the countries that have adopted the UNCITRAL Model Law into their legislation. ${ }^{91}$ The UNCITRAL Model Law is designed in a way that requires the recognition and enforcement of an arbitral award irrespective of the country in which it was made.

\section{Public Order and Morals}

For a foreign arbitral award to be recognized and enforced in Ethiopia, it must be consistent and in accord with the public order or morals in Ethiopia. ${ }^{92}$ As noted by Ibrahim Idris: "Public order is a doctrine which serves as a safety valve for country to enable its courts to deny effect foreign laws and judgments which, for one reason or another, should not be enforced."93

Public order is also referred to as public policy or ordre public. ${ }^{94}$ Despite its expansive usage in the enforcement of foreign judgments and foreign arbitral awards, the concept of public policy is very difficult to define. Nor does it have a specific content; it is very malleable, to say the least. At times, public policy

${ }^{90}$ Julian Lew et al (2003), Comparative International Commercial Arbitration, (The Hague, London, New York: Kluwer Law International), p.702.

${ }^{91}$ By the end of 2010, the number of countries that have modeled their modern arbitration laws on the UNCITRAL Model Law has reached more than 60 countries and 7 states of the United States of America. For more on this, see $<$ www.uncitral.org/ > (Last visited on January 10, 2011).

${ }^{92}$ Art. 461(1)(e) of CPC.

${ }^{93}$ Ibrahim Idris, supra note 23, p.30.

${ }^{94}$ In this work, the word 'public policy' is employed as is preferably used in the international commercial arbitration in relation to the recognition and enforcement of foreign arbitral awards. 
has been branded as a very unruly horse, and "once one gets astride it he never knows where it will carry him". 95

It has been submitted that public policy in international commercial arbitration is a double-edged sword: helpful as a tool, dangerous as a weapon. ${ }^{96}$ It operates as a shield to the enforcement of foreign awards, which bear unwanted solutions, i.e., it serves as safety valve in the forum's legal system, protecting it from the application of foreign rules that might produce unbearable results. This is necessitated by the fact that international arbitration being a substitute for national courts, arbitrators should not be allowed to disregard public interests that would otherwise be protected by the judges. Thus, public policy may be considered:

A defense which is available to the courts against foreign rules or court decisions and arbitral awards, the application and, respectively, enforcement of which might produce results that are inconsistent with the fundamental economic, legal, moral, religious, social, and political standards or principles of the forum state ... the judge has to uphold those principles and standards which are so sacrosanct as to require maintenance at all costs and without exception. ${ }^{97}$

On the other hand, it can also be a sword in the hands of those who want to limit the mobility or finality of international commercial awards. Moreover, the fact that different states have differing concepts of their own public policy means that there is a risk that a particular state may not enforce an award that another state would regard as valid. ${ }^{98}$ However, lack of due process, lack of equality between the parties, partiality of the arbitrators, the non-performance of contracts in good faith, usurious interest, peddling and kickbacks in international commercial arbitration, are against international public policy. ${ }^{99}$

The concept of morality also refers to the fact that those foreign arbitral awards appearing repugnant to the conduct, customs or accepted practices of the society of the recognition forum would not be carried out. ${ }^{100}$ In spite of some ambiguities in relation with moral issues, states generally would not tolerate drug-smuggling, child pornography, bribery, corruption, prostitute-trafficking and other generally condemned practices.

${ }^{95}$ ILA Committee on International Commercial Arbitration (2000), 'Public Policy as a Bar to the Enforcement of International Arbitral Awards', London Conference Report, p.248.

${ }^{96}$ Ibid.

${ }^{97}$ Ibid.

${ }^{98}$ Ibid.

${ }^{99}$ Ibid.

${ }^{100}$ Ibrahim Idris, supra note 23, p.30. 
To sum up, public policy, by its very nature, is dynamic. Eventually, a lot remains to be desired on the certainty and predictability thereof. However, the general trend, in the recognition and enforcement of foreign arbitral awards, is that in applying their own public policy, states should give it an international rather than a domestic dimension.

\section{Arbitrability of the Subject Matter}

The concept of arbitrability has attracted scholarly attention and academic discource. ${ }^{101}$ Suffice it to reproduce here the words of Redfern and Hunter:

Where certain disputes should, as a matter of public policy, only be adjudicated by the sovereign-appointed judges, the substantive laws provide that such disputes can never be disposed of by private adjudication, i.e., arbitration. Arbitrability involves determining which types of dispute may be resolved by arbitration and which belong exclusively to the domain of the courts. ${ }^{102}$

Thus, pursuant to Art. 461(1)(e) of CPC, in order for a foreign arbitral award to be recognized and enforced in Ethiopia, the award must relate to matters that, under the provisions of Ethiopian laws, can be submitted to arbitration. In other words, it means that the dispute for the resolution of which a foreign arbitral award is given must be capable of being arbitrated, i.e. it must be arbitrable in Ethiopia in order for it to be recognized and enforced in Ethiopia.

The issue of arbitrability in international commercial arbitration is crucial. Parties to international commercial arbitration must always be well aware of what are arbitrable (i) under the laws of the place of the seat of arbitration, i.e. lex loci arbitri, (ii) under the laws of the state to which the parties would like to refer to as governing their arbitral procedures (lex electionis) other than the lex loci arbitri, if any, and (iii) under the laws of the state in which recognition and enforcement may ultimately be sought. In the event that the commercial dispute submitted to arbitration is not arbitrable in accordance with the lex loci arbitri and in rare cases, the arbitration laws of the state to which the parties have

${ }^{101}$ In Ethiopia, for example, the issue has been dealt with by various scholars. See Zekarias Keneaa (1994), 'Arbitrability in Ethiopia: Posing the Problem', Journal of Ethiopian Law, Vol.XVII, pp.116-136; Bezawork Shimelash (1994), 'The Formation, Content and Effect of an Arbitral Submission Under Ethiopian Law', Journal of Ethiopian Law, Vol.XVII, pp.69-94;Tilahun Teshome (2007), 'The Legal Regime Governing Arbitration in Ethiopia: A Synopsis', Ethiopian Bar Review, Vol.1, No.2, pp.117-140; Tecle Hagos Bahta (2009), 'Adjudication and Arbitrability of Government Construction Contract Disputes’, Mizan Law Review, Vol. 3, No.1, pp.1-32.

${ }^{102}$ Redfern and Hunter, supra note 4, at 3-21. 
referred to as governing the arbitral proceedings (lex electionis), it will be prone to the set aside recourse in the country where the award is made. ${ }^{103}$

What happens when a dispute, incapable of being submitted to arbitration in Ethiopia, has been validly submitted to arbitration in the country where the award is made lands in the Ethiopian courts having been already granted the order of exequatur as per Art. 457(b) of the CPC? Clearly, as per Art. 461(1)(e) of the CPC, it cannot be recognized and enforced in Ethiopia. What disputes are, therefore, non-arbitrable, in Ethiopia, by reason of which our courts would dismiss the application for the recognition and enforcement of foreign arbitral awards? To answer this question, suffice it to say that the non-arbitrability of a subject matter should be proven by showing that a particular court has exclusive jurisdiction to adjudicate the matter or that a particular legislative enactment prohibits the submission of the disputes in connection with a particular subject matter to arbitration. Thus, if the enforcement of a foreign arbitral award which settles disputes arising from or relating to subject matters that are not capable of being submitted to arbitration is sought, the Ethiopian courts are expected to dismiss the application for the enforcement thereof.

As stated earlier, the issue of arbitrability is a public policy issue and a court is required to reject it, sua sponte, on the ground that the dispute is nonarbitrable. The UNCITRAL Mode Law, taken as the international minimum standard, also approaches it in a similar way. The UNCITRAL Model Law provides that an arbitral award may be set aside by the courts if the courts ex officio find that the subject matter of the dispute is not capable of settlement by arbitration under the law of this state. ${ }^{104}$ Similarly, the New York Convention employs similar approach in the process of recognition and enforcement of foreign arbitral awards. Thus, our courts should be vigilant of what is arbitrable and what is not in Ethiopia in dealing with the recognition and enforcement of foreign arbitral awards proceedings.

\section{International Conventions}

Art. 456 (1) of CPC states that "Unless otherwise expressly provided for by international conventions, foreign judgments may not be executed in Ethiopia except in accordance with the provisions of [the] chapter" that deals with the Execution of Foreign Judgments and Awards, i.e. Articles 456 to 461 of the CPC. [Emphasis added]. This provision also applies by analogy when the enforcement of a foreign award is sought. From the reading of this provision, it can be seen that courts are required to strictly follow the provisions (Arts. 456-

\footnotetext{
103 See above notes 42-45 and the accompanying text.

${ }^{104}$ Art. 34(2)(b)(i) of the UNCITRAL Model Law
} 
461) provided for the recognition and enforcement of foreign judgments and foreign arbitral awards in Ethiopia. It is also clear that there is only one situation in which courts can shun the 'golden rules' that feature in under Art. 461 of CPC as a precondition to be fulfilled for the recognition and enforcement of foreign arbitral awards. In other words, international conventions can expressly provide the conditions for the recognition and enforcement of foreign arbitral awards that derogate from the conditions already stated in the CPC.

There may be bilateral, plurilateral and multilateral conventions dealing with the recognition and enforcement of foreign arbitral awards. Prominent and successful multilateral conventions include the New York Convention. ${ }^{105}$ The Convention has been praised as: "the single most important pillar on which the edifice of international arbitration rests." ${ }^{106}$ And yet, Ethiopia is not a party to this Convention. The need for ratification of the Convention is long felt by the Ethiopian business community. ${ }^{107} \mathrm{~A}$ thorough research undertaking by the concerned bodies on the pros and cons of ratifying it is, indeed, long overdue.

Assuming, however, that Ethiopia is a party to the New York Convention without declaring the reciprocity reservation, Ethiopian courts, seized with an application for the recognition and enforcement of a foreign award, will apply the Convention rules irrespective of where (Convention or Non-convention state) the foreign award is made. ${ }^{108}$ On the other hand, if Ethiopia becomes a party to the Convention, declaring the reciprocity reservation, foreign awards made, in those countries, which are parties to the Convention, will be recognized and enforced in accordance with the conditions of the New York Convention. In this case, the requirements under Art. 461 of CPC will be

\footnotetext{
${ }^{105}$ As of September 2010, the number of ratifying states has reached 145 states.

${ }^{106}$ Redfern and Hunter, supra note 4, at 10-22.

107 'Imperative Ethiopia Sign 1958 New York Convention: Chamber of Commerce', The Sub-Saharan Informer (October 22, 2004), English Newspaper (Ethiopia), (wherein the then Addis Ababa Chamber of Commerce (AACC, now AACCSA). Arbitration Institute stressed the need for the country to be a signatory of the 1958 New York Convention). See also Booz Allen Hamilton (2008), Reinforcing Ethiopia's International Trade Law Framework For a Stronger Business Environment: A Case for the Ratifications of the New York Convention and CISG, implemented under the auspices of the USAID- WTO Accession Plus Project (On file with the Author).

${ }^{108}$ On the other hand, if Ethiopia becomes party to the Convention by registering the 'reciprocity' reservation, Ethiopian courts should apply two sets of requirements based on whether the rendering country is a Convention country or a nonConvention country. In such cases, the Convention rules and the CPC rules apply respectively.
} 
superseded. However, Art. 461 of CPC will remain in force for the foreign arbitral awards made in the countries, which are not parties to the Convention.

Some Conventions are even more sweeping in their application. The most interesting convention in this regard is the ICSID Convention. ${ }^{109}$ The main purpose of the Center, it is claimed, is to facilitate the settlement of international investment disputes between ratifying host (investee) states and nationals (foreign investors) of other ratifying states $^{110}$ and thereby promote foreign investment. ${ }^{111}$ ICSID provides a system of dispute settlement that is specialized in investor-state disputes.

Ethiopia signed the ICSID Convention on September 21, $1967^{112}$ and yet, Ethiopia has not ratified it. Pursuant to Art. 9(4) of the Federal Constitution, international agreements become the integral part of the law of the land of Ethiopia only if they are ratified. ${ }^{113}$ Thus, Ethiopia is not a party to the ICSID Convention.

Once again, let us assume, for the purpose of our discussion here, that Ethiopia is a party to the ICSID Convention. Let's further assume that a foreign investor, whose country is a party to the Convention, invests in Ethiopia and a dispute arises out of the investment contract. Art. 22(2) of the former Investment Proclamation (i.e. Proclamation No. 37/ 1996) ${ }^{114}$ provided the following:

A dispute not amicably settled may be submitted to the competent court of the country or to international arbitration within the framework of any bilateral or multilateral agreement to which the Government and the country of which the foreign investor is a national are contracting parties.

Failing a compromise, such provisions enable the dispute to be submitted to ICSID for arbitration. If the foreign investor emerges victorious (award creditor) and seeks to enforce the award in Ethiopia, the recognition and enforcement will

109 The International Center for the Settlement of Investment Disputes (ICSID) was established by the World Bank Group under the 1965 Convention on the Settlement of Investment disputes between States and Nationals of Other States (also known as the Washington Convention). The full text of the Convention as well as the list of ratifying states is available at: <www.worldbank.org/ICSID/> (Last visited on January 10, 2011). As of January 2010, 155 countries have signed and 144 have ratified the Convention.

${ }^{110}$ See the Preambular fourth recital to the Convention.

${ }^{111}$ See Redfern and Hunter, supra note 4, at 10-49.

${ }^{112}$ Ibid.

113 Art. 9(4) of the Federal Constitution.

114 This proclamation had been repealed by virtue of Art.40 of the Investment Proclamation No.280/2002, July 2, 2002. It is to be noted that Proclamation No. 280/2002 lacks a counterpart provision. 
proceed in accordance with the rules under the ICSID Convention. Concerning the recognition and enforcement of an ICSID-arbitral award, Redfern and Hunter noted: ${ }^{115}$

Unless an ICSID award is revised or annulled under ICSID's own internal procedures, each contracting state must recognize and enforce an ICSID award as if it were a final judgment of its own courts.

It means that ICSID awards are recognized and enforced short of any scrutiny in the country in which recognition and enforcement is sought.

\section{Conclusion}

The Civil Procedure Code does not define foreign arbitral award. Until such time that the Ethiopia can have new modern commercial arbitration laws (domestic and international), it is left to the discretion of courts to offer meaning to the term. Although it is far from an exhaustive list, some criteria by which the nationality of an arbitral award rendered in international commercial arbitration proceeding can be determined are alluded to.

Apart from the formalities to be met, the conditions set forth for the recognition and enforcement of a foreign arbitral award are in general: (i) that reciprocity must be ensured, (ii) that the award must have been given pursuant to a valid arbitration agreement or that it must have been given in accordance with the law of the rendition state, (iii) that due process of law, particularly the equality of the parties, has been properly heeded throughout the process, (iv) that the arbitral tribunal had been regularly constituted, (v) that the award does not relate to a subject matter which is not capable of being submitted to arbitration in Ethiopia, (vi) that the award is not contrary to public order or morals, and (vii) that the award can be executed under the prevailing Ethiopian laws.

In this Article it has been particularly shown that the applicability of the doctrine of reciprocity as a condition for the recognition and enforcement of international commercial awards is significantly on the wane owing mainly to the New York Convention and the UNCITRAL Model Law. Thus, it is suggested that Ethiopian courts should extricate themselves from the existing conundrum (especially discussed above in relation to its erroneous interpretation and application in the recognition and enforcement of foreign judgments) and apply it in a manner that encourages the international mobility of arbitral awards.

\footnotetext{
${ }^{115}$ Redfern and Hunter, supra note 4, at 10-49.
} 
Finally, it should be pointed out that the existing arbitration laws in Ethiopia do not match up with the current development in international commercial arbitration. The recent move of the House of the Federation in 'communitarizing' the arbitration law is commendable. Thus, the Federal Government is expected to come up with modern arbitration laws (either modeled on the UNCITRAL Model Law or a tailor-made of its own). Such arbitration laws not only can enhance Ethiopia's attraction as a venue for international commercial and investment arbitration, but will also cater for the needs of the Ethiopian business community for a modern arbitral system commensurate with its domestic and transnational business and investment transactions. 